\title{
PENGARUH KESADARAN MERK, PERSEPSI KUALITAS, DAN LOYALITAS MERK TERHADAP KEPUTUSAN PEMBELIAN HANDPHONE VIVO PADA ANGKASA CELL DI KOTA SEMARANG
}

\author{
Ana Putri Nastiti, Diva Riza Fahlefi \\ STIE SEMARANG \\ Putri25ananta@gmail.com
}

\begin{abstract}
The increasing competition between similar products, the companies compete with each other to win over consumers. The purpose of this study was to find out whether brand awareness, perceived quality of brand loyalty towards the purchase decision of the Vivo handphone on the cell space in Semarang Regency. The population in this study were all customers or consumers who used or made mobile phone purchasing decisions on space cells in Semarang Regency, totaling 154 customers. purpose sampling, namely the selection of samples based on certain characteristics to 63 respondents. The method of data analysis uses multiple linear regression, coefficient of determination and hypothesis testing. The results of this study show that the regression coefficient value of brand awareness is 0.301, tcount (3.958)> t table (1.66) and sign (0.000) <(0.05) means that brand awareness has a positive and significant influence on purchasing decisions. The qualification perception regression coefficient value is 0.303. tcount (3.694)> t table (1.66) and sign $(0,000)<(0.05)$, meaning that the perception of quality has a positive and significant influence on purchasing decisions. The regression coefficient value Brand loyalty is 0.242. tcount $(3,438)>t$ table $(1,66)$ and sign $(0,001)<(0,05)$, means that brand loyalty has a positive and significant influence on purchasing decisions. Brand awareness, Perception of Brand Loyalty Quality together - have a positive and significant effect on purchasing decisions, this is evidenced in the $F$ test which obtained $F$ count of 37.095 and signification value of $0.000<0.05$. Determination Coefficient test results $R 2$ is 0.616 means brand awareness, Perception Quality Brand loyalty has the role of 61.6\%, together - able to explain the purchase decision variables, while the remaining $64.2 \%$ explained other variables. Based on the results of research on the purchase decision of Vivo cellphones in space cells in Semarang Regency in the medium category, and approved to increase brand awareness offered, thus increasing consumer confidence in cellphones on cellular phones
\end{abstract}

Keywords: Brand Awareness,Perception of Brand Loyalty Quality and Purchasing Decision.

\section{ABSTRAK}

Semakin meningkatnya persaingan antar produk sejenis, maka perusahaan saling bersaing merebutkan konsumen. Tujuan dalam penelitian ini adalah, untuk mengetahui apakah Kesadaran merk, Persepsi Kualitas Loyalitas merk terhadap Keputusan Pembelian handphone Vivo pada angkasa cell di Kota Semarang.

Populasi dalam penelitian ini adalah seluruh pelanggan atau konsumen, yang menggunakan atau melakukan keputusan pembelian handphone pada angkasa cell di Kota Semarang, berjumlah 154 pelanggan. purpose sampling yaitu pemilihan sampel berdasar pada karakteristik tertentu menjadi 63 responden. Metode analisis data menggunakan regresi linier berganda, koefisien determinasi dan uji hipotesis.

Hasil dari penelitian ini menunjukan dengan nilai koefesien regresi Kesadaran merk sebesar 0,301 , nilai $t_{\text {hitung }}(3,958)>t_{\text {tabel }}(1,66)$ dan sign $(0,000)<(0,05)$ berarti Kesadaran merk memiliki pengaruh positif dan signifikan terhadap keputusan pembelian. Nilai koefesien regresi persepsi kualitas sebesar 0,303 . nilai $t_{\text {hitung }}(3,694)>t_{\text {tabel }}(1,66)$ dan $\operatorname{sign}(0,000)<(0,05)$, berarti 
persepsi kualitas memiliki pengaruh positif dan signifikan terhadap keputusan pembelian. Nilai koefesien regresi Loyalitas merk sebesar 0,242 . nilai $t_{\text {hitung }}(3,438)>t_{\text {tabel }}(1,66)$ dan sign $(0,001)$ $<(0,05)$, berarti Loyalitas merk memiliki pengaruh positif dan signifikan terhadap keputusan pembelian. Kesadaran merk, Persepsi Kualitas Loyalitas merk bersama - sama berpengaruh positif dan signifikan terhadap keputusan pembelian, hal ini di buktikan pada uji $\mathrm{F}$ yang

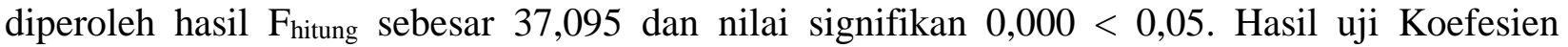
determinasi R2 sebesar 0,616 berarti Kesadaran merk, Persepsi Kualitas Loyalitas merk mempunyai peran $61,6 \%$, secara bersama - sama mampu menjelaskan variabel keputusan pembelian, sedangkan sisanya $64,2 \%$ di jelaskan variabel lain.

Berdasarkan hasil penelitian bahwa keputusan pembelian handphone Vivo pada angkasa cell di Kota Semarang dalam kategori sedang, dan disarankan untuk meningkatkan kesadaran merk yang ditawarkan, sehingga kepercayaan konsumen pada merk handphone Vivo pada angkasa cell di Kota Semarang semakin kuat dan keputusan pembelian semakin meningkat

Kata kunci: Kesadaran Merk, Persepsi Kualitas Loyalitas Merk Dan Keputusan Pembelian.

\section{PENDAHULUAN}

Perkembangan dunia bisnis saat ini menunjukkan kemajuan yang sangat pesat, dengan tujuan untuk mendorong kemajuan ilmu pengetahuan dan tekhnologi. Hal ini dapat dilihat dengan banyaknya perusahaan yang bermunculan serta bersaingnya antar produk dan pelayanan. Semakin meningkatnya persaingan antar produk sejenis, maka perusahaan saling bersaing merebutkan konsumen.

Telepon selular merupakan perkembangan dari telepon rumah yang dapat dibawa kemana saja, karena handphone bersifat mobile dan juga dapat membantu kegiatan manusia bukan hanya untuk menelpon namun dapat mengirim sms / pesan, internet, mendengarkan musik, bahkan mengabadikan kegiatan manusia dengan teknologi kamera. Semakin lama pola pikir konsumen akan selalu berubah sesuai dengan perkembangan jaman. Konsumen saat ini sangatlah kritis dalam memilih suatu produk, sampai pada keputusan untuk membeli produk tersebut.

Produk handphone semakin berkembang dan memanjakan konsumen dengan berbagai kelebihan yang dimiliki. Pada saat ini muncul banyak merk dipasar yang menawarkan berbagai fitur atau perbedaan produk dengan harga yang lebih murah dibanding merk lain di pasar. Hal ini membuat konsumen mempunyai banyak pilihan dalam mengambil keputusan membeli. Kualitas handphone berpengaruh besar dalam pengambilan keputusan membeli. Dengan harga yang lebih terjangkau dengan merk yang banyak memberikan kualitas handphone dengan fitur terbaru. Handphone Vivo adalah salah satu merk handphone yang berasal dari negara China yang sudah masuk ke Indonesia yang namanya mulai dikenal masyarakat Indonesia karena memiliki fitur kamera yang bagus dan design yang up to date. 
Ketika melakukan pembelian maka konsumen akan mempertimbangkan beberapa hal dalam pikirannya. Dan seseorang yang akan sadar atas merk tersebut dengan siap untuk segera melakukan tindakan. Demikian juga dengan asosiasi merk yang ada terhadap sebuah produk atau merk yang sama dalam benak setiap konsumen berbeda-beda. Presepsi kualitas merupakan proses yang menyangkut masuknya pesan atau informasi kedalam otak manusia, melalui persepsi manusia terus menerus mengadakan hubungan dengan lingkungannya. Selain presepsi kualitas loyalitas merk juga merupakan perubahan perilaku seseorang yang timbul dari pengalaman masa lalunya. Konsumen memperoleh berbagai pengalamannya dalam pembelian produk, mengkonsumsi produk, dan merk produk apa yang disukainya. Loyalitas merk merupakan aspek terprogram yang dilakukan oleh manusia untuk mendapatkan informasi atau pengetahuan yang akan digunakan dalam memperloeh suatu hal yang diinginkan.

Demikian juga loyalitas merk yang sudah melekat merupakan hal yang tidak kalah pentingnya. Loyalitas merk adalah evaluasi, perasaan emosi, dan kecenderungan tindakan yang menguntungkan atau tidak menguntungkan dan bertahan lama pada seseorang terhadap suatu objek atau gagasan tertentu.

\section{KAJIAN TEORITIS}

Pengertian Keputusan Pembelian

Menurut Hawkins. (2007), keputusan pembelian adalah sebagai suatu kegiatan membeli kembali yang dilakukan oleh konsumen terhadap suatu produk dengan merek yang sama tanpa diikuti oleh perasaan yang berarti terhadap produk tersebut. Terdapat dua kemungkinan yang dapat menyebabkan seseorang melakukan pembelian ulang suatu produk. Pertama, konsumen merasa puas dengan pembelian yang mereka lakukan. Kedua, pelanggan merasa tidak puas, tetapi mereka tetap melakukan pembelian ulang. Untuk kemungkinan kedua ini biasanya disebabkan mereka menganggap biaya yang harus mereka keluarkan untuk mencari, mengevaluasi, dan mengadopsi produk dengan merek lain (switching cost) terlalu tinggi.

Sedangkan menurut Cronin dan Morris (1989), keputusan pembelian adalah sesuatu pada komitmen terhadap produk atau jasa yang timbul setelah menggunakan mereka, sehingga timbul gagasan untuk konsumsi lagi.

Menurut Peter dan Olson (2000), keputusan pembelian ulang adalah ketika konsumen melakukan pembelian ulang karena adanya suatu dorongan dan perilaku membeli secara berulang yang dapat menumbuhkan suatu loyalitas terhadap apa yang dirasakan sesuai untuk dirinya. 


\section{Pengertian Merek}

Menurut Aaker (1997) merek adalah nama dan atau simbol yang bersifat membedakan (seperti sebuah logo, cap, atau kemasan) dengan maksud mengidentifikasi barang atau jasa dari seorang penjual atau sebuah produk tertentu, dengan demikian membedakannya dari barang-barang dan jasa yang dihasilkan pesaing. Jadi merek mengidentifikasi penjual atau pembuat merek dapat berupa nama, merek dagang, logo, atau simbol lain.

Sedangkan menurut Kotler (2001), merek adalah nama, istilah, tanda atau rancangan, atau kombinasi dari semua ini yang dimaksudkan untuk mengidentifikasikan produk atau jasa dari satu atau kelompok atau membedakannya dari produk pesaing.

Menurut Kartajaya (2004) merek adalah kelengkapan produk, jadi setiap produk harus memiliki merek, sehingga konsumen tidak mengalami kesulitan dalam mencari produk kembali produk tersebut. Merek juga mempunyai fungsi untuk membedakan kualitas produk yang satu dengan yang lainnya. Selain itu merek juga merupakan suatu jaminan dari produsen atas kualitas dari produk yang dihasilkan.

\section{Kesadaran Merek (Brand Awareness)}

Menurut Aaker (1996), kesadaran merek adalah kesanggupan seorang calon pembeli untuk mengenali atau mengingat kembali bahwa suatu merek merupakan bagian dari kategori produk tertentu.

Sedangkan menurut Durianto. (2004). Brand awareness atau kesadaran merek menggambarkan kesanggupan seorang calon pembeli untuk mengenali, mengingat kembali suatu brand sebagai bagian dari suatu kategori produk tertentu. Pada umumnya konsumen cenderung membeli produk dengan brand yang sudah dikenalnya atas dasar pertimbangan kenyamanan, keamanan dan lain-lain. Bagaimanapun juga brand yang sudah dikenal menghindarkan konsumen dari risiko pemakaian dengan asumsi bahwa brand yang sudah dikenal dapat diandalkan.

\section{Persepsi Kualitas (Perception Quality)}

Menurut Schiffman dan Kanuk (2008) persepsi kualitas adalah penilaian konsumen terhadap kualitas barang atau jasa yang berdasarkan informasi yang diterima berdasarkan asosiasi terhadap produk tersebut. Sedangkan menurut Aaker (1991) persepsi kualitas adalah sebagai persepsi pelanggan terhadap keseluruhan kualitas atau keunggulan suatu produk atau jasa layanan berkaitan dengan apa yang diharapkan oleh pelanggan.

Menurut Aaker (1997) menjelaskan persepsi kualitas yaitu konsumen terhadap keseluruhan kualitas atau keunggulan suatu produk atau jasa berkaitan dengan yang diharapkan 
oleh konsumen. Selanjutnya Aaker menegaskan satu hal yaitu bahwa persepsi kualitas merupakan persepsi para konsumen, oleh sebab itu persepsi kualitas tidak dapat diterapkan secara obyektif. Selain itu persepsi kualitas, konsumen akan melibatkan apa yang penting untuk konsumen karena setiap konsumen memiliki kepentingan yang berbeda-beda terhadap suatu produk atau jasa.

\section{Loyalitas Merk (Brand Loyalty)}

Menurut Schiffman dan Kanuk (2009), loyalitas merek adalah preferensi konsumen secara konsisten untuk melakukan pembelian pada merek yang sama pada produk yang spesifik atau kategori pelayanan tertentu. Loyalitas merek adalah sebuah komitmen yang kuat dalam berlangganan atau membeli suatu merek secara konsisten di masa yang akan datang.

Menurut Mowen \& Minor (2002), (brand loyalty) dipandang sebagai sejauh mana seorang pelanggan menunjukan sikap positif terhadap suatu merek, mempunyai komitmen pada merek tertentu, dan berniat untuk terus membelinya dimasa depan. Menurut Aarker dalam Nagar (2009) berpendapat bahwa loyalitas merek menujukan pola pembelian yang konsisten terhadap merek tertentu sepanjang waktu dan juga sikap menyenangkan terhadap sebuah merek. Loyalitas merek berkembang ketika merek sesuai dengan personalitas atau image diri konsumen atau ketika merek menawarkan kepuasan dan keuntungan unik yang dicari konsumen.

Sedangkan menurut Giddens (2002) menyebutka loyalitas merek adalah pilihan yang dilakukan konsumen untuk membeli merek tertent dibandingkan merek yang lain dalam satu kategori produk. Hal ini terjadi karena konsumen merasa bahwa merek menawarkan fitur produk yang tepat, gambar atau tingkat kualitas diharga yang tepat. Sedangkan menurut Sutisna (2001) loyalitas merek (brand loyalty) bisa didefinisikan sebagai sikap menyenangi suatu merek yang diwujudkan dalam pembelian yang konsisten terhadap merek itu sepanjang waktu.

Gambar 2.1

Kerangka pemikiran

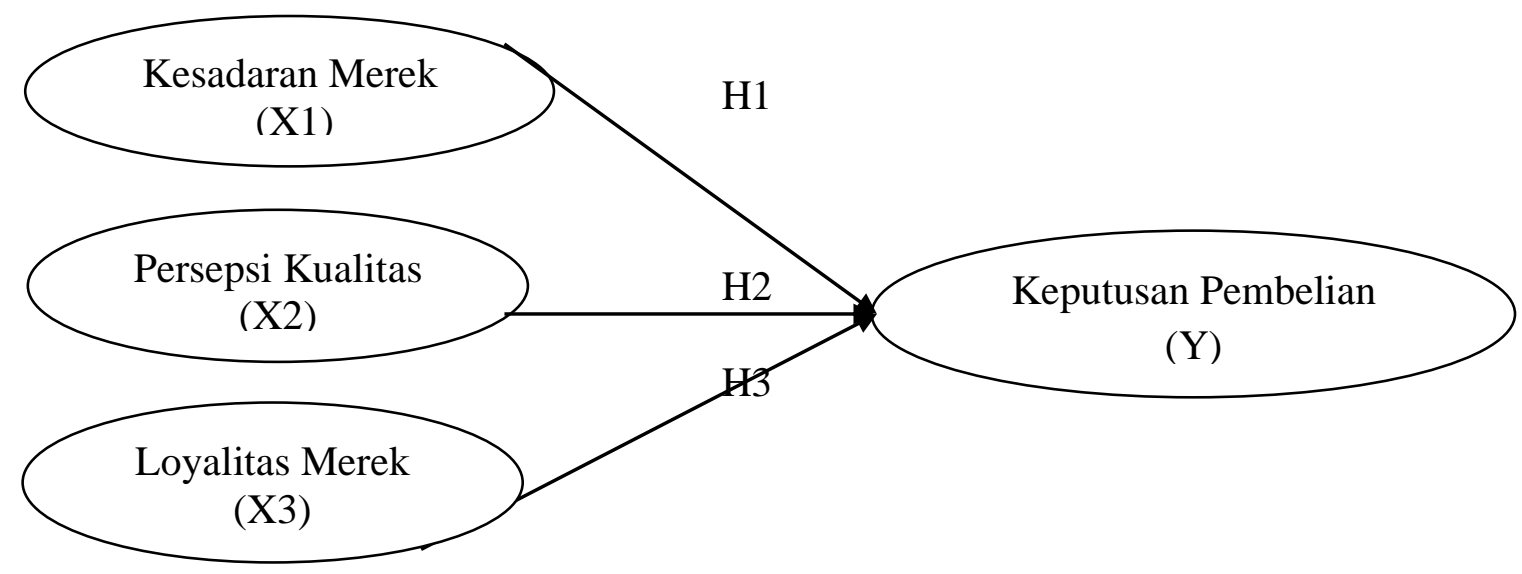




\section{METODOLOGI}

Populasi merupakan gabungan seluruh elemen yang memiliki serangkaian karakteristik serupa untuk kepentingan riset (Malhotra, 2005) serta sekumpulan unsur atau elemen yang menjadi obyek penelitian, dapat berupa lembaga, individu, kelompok, dokumen, atau konsep.

Populasi dalam penelitian ini adalah seluruh pelanggan atau konsumen, yang menggunakan atau melakukan keputusan pembelian handphone pada angkasa cell di Kota Semarang, berjumlah 654 pelanggan.

Adapun karakteristik yang digunakan dalam pengambilan sampel adalah. Konsumen angkasa cell di Kota Semarang. Telah melakukan transaksi pembelian angkasa cell di Kota Semarang. Karakteristik ini diambil dengan alasan bahwa konsumen yang telah melakukan transaksi pembelian cenderung merupakan konsumen yang melakukan keputusan pembelian jadi sampel dalam penelitian ini adalah Handphone Merek Vivo berjumlah 63

Variabel penelitian menurut Sugiyono (2007) adalah segala sesuatu hal yang berbentuk apa saja yang ditetapkan oleh peneliti untuk dipelajari sehingga diperoleh informasi tentang hal tersebut, dan kemudian ditarik kesimpulannya. Variabel bebas (independen) dalam penelitian ini adalah modal yang diukur dalam penelitian ini adalah:

1. Kesadaran Merek $\left(\mathrm{X}_{1}\right)$ Brand awareness atau kesadaran merek menggambarkan kesanggupan seorang calon pembeli untuk mengenali, mengingat kembali suatu brand sebagai bagian dari suatu kategori produk tertentu.

2. Persepsi Kualitas $\left(\mathrm{X}_{2}\right)$, Persepsi kualitas merupakan persepsi para konsumen, oleh sebab itu persepsi kualitas tidak dapat diterapkan secara obyektif

3. Loyalitas Merek $\left(\mathrm{X}_{3}\right)$, Loyalitas merek adalah preferensi konsumen secara konsisten untuk melakukan pembelian pada merek yang sama pada produk.

Menurut Sugiyono (2007). Variabel Dependen merupakan variabel yang dipengaruhi akibat karena adanya variabel bebas. Variabel terikat dalam penelitian ini adalah Keputusan pembelian adalah Keputusan pembelian adalah sebagai suatu kegiatan membeli kembali yang dilakukan oleh konsumen terhadap suatu produk dengan merek yang sama tanpa diikuti oleh perasaan yang berarti terhadap produk tersebut.

Metode analisa data dalam penelitian ini adalah: Uji Asumsi Klasik. Tujuan pengujian asumsi klasik ini adalah untuk menguji dan mengetahui kelayakan atas model regresi yangdigunakan dalam penelelitian ini, pengujian meliputi: Uji Normalitas, Uji Multikolinieritas, Uji Heteroskedastisitas. 
Uji Signifikansi Parameter Individual (Uji Statistik t), Uji signifikansi Simultan (Uji statistik F), Koefisien Determinasi (R2), Analisis regresi linier berganda

$$
\begin{aligned}
\mathrm{Y}= & \beta_{0}+\beta_{1} \text { Kesadaran Merek }+\beta_{2} \text { Persepsi Kualitas }+\beta_{3} \text { Loyalitas Merek }+\varepsilon \\
& \mathrm{X} 1=\text { Kesadaran Merek } \\
& \mathrm{X} 2=\text { Persepsi Kualitas } \\
& \mathrm{X} 3=\text { Loyalitas Merek } \\
& \mathcal{E}=\text { kesalahan residual (eror) }
\end{aligned}
$$

\section{PEMBAHASAN}

Berikut ini akan dijelaskan mengenai karakteristik responden berdasarkan, jenis kelamin, dan penghasilan. Tabel berikut adalah tabulasi responden berdasarkan jenis kelamin.

Tabel 1

Responden Berdasarkan Jenis Kelamin

\begin{tabular}{|l|c|c|}
\hline \multicolumn{1}{|c|}{ Jenis Kelamin } & Jumlah & Prosentase (\%) \\
\hline Perempuan & 38 & $70 \%$ \\
\hline Laki-Laki & 25 & $30 \%$ \\
\hline Jumlah & 63 & $100 \%$ \\
\hline
\end{tabular}

Sumber: Data primer yang diolah 2019

Berdasarkan pada tabel diatas dapat diketahui bahwa sebagian besar responden pada penelitian ini adalah responden perempuan yaitu 38 orang atau $70 \%$ dan reponden laki-laki sebanyak 25 orang atau $30 \%$.

Tabel 2

Responden Berdasarkan Penghasilan

\begin{tabular}{|l|c|c|}
\hline \multicolumn{1}{|c|}{ Penghasilan/(Bulan) } & Jumlah & Prosentase (\%) \\
\hline$<2$ juta & 27 & $56 \%$ \\
\hline $3-4$ juta & 16 & $17 \%$ \\
\hline$>4$ juta & 20 & $27 \%$ \\
\hline Jumlah & 63 & $100 \%$ \\
\hline
\end{tabular}

Sumber: Data primer yang diolah 2019

Berdasarkan pada tabel diatas dapat diketahui bahwa sebagian besar responden pada penelitian ini adalah responden berpenghasilan kurang dari 2 juta per bulan sebanyak 27 orang 56 $\%$ dan sebanyak 16 orang yang berpenghasilan 3-4 juta per bulan sebanyak $17 \%$ dan 20 orang berpengahasilan lebih dari 4 juta per bulan sebanyak $27 \%$ 


\section{Analisis regresi Linier Berganda}

Analisis regresi linier berganda pada dasarnya adalah studi mengenai ketergantungan variabel dependen (terikat) dengan satu atau lebih variabel independen, hasil dari uji regresi linier berganda adlah sebagai berikut:

Tabel 4

Regresi Linier Berganda

Coefficientsa

\begin{tabular}{|rl|r|r|}
\hline \multicolumn{2}{|c|}{ Model } & \multicolumn{2}{|c|}{ Unstandardized Coefficients } \\
\cline { 3 - 4 } & & B & \multicolumn{1}{|c|}{ Std. Error } \\
\hline \multirow{3}{*}{1} & (Constant) & .824 & 1.408 \\
& Kesadaran Merk & .301 & .076 \\
& Persepsi Kualitas & .303 & .082 \\
& Loyalitas Merk & .242 & .070 \\
\hline
\end{tabular}

a. Dependent Variable: Keputusan Pembelian

Dari hasil analisis dengan program SPSS versi 16 tersebut, maka dapat diketahui persamaan regresi dari penelitian ini. Adapaun persamaan regresi linier yang terbentuk adalah:

$$
Y=0,824+0,301 X_{1}+0,303 X_{2}+0,0,242 X_{3} .
$$

1. Uji Koefisien Determinasi

Uji ini digunakan untuk mengetahui seberapa besar pengaruh variabel bebas secara bersama-sama terhadap variabel terikat. Namun kelemahan mendasar penggunaan koefisien determinasi $\left(\mathrm{R}^{2}\right)$ adalah bias terhadap jumlah variabel independen (bebas) yang dimasukkan ke dalam model. Hasil dari koefisien determinasi sebagai berikut:

Tabel 5

Koefisien Determinasi

Model Summary ${ }^{b}$

\begin{tabular}{|l|r|r|r|r|r|}
\hline Model & \multicolumn{1}{|c|}{$\mathrm{R}$} & $\mathrm{R}$ Square & $\begin{array}{c}\text { Adjusted R } \\
\text { Square }\end{array}$ & $\begin{array}{c}\text { Std. Error of the } \\
\text { Estimate }\end{array}$ & Durbin-Watson \\
\hline 1 & $.811^{\mathrm{a}}$ & .658 & .641 & 1.49772 & 2.014 \\
\hline
\end{tabular}

a. Predictors: (Constant), Loyalitas Merk, Kesadaran Merk, Persepsi Kualitas

b. Dependent Variable: Keputusan Pembelian

Berdasarkan tabel diatas menunjukkan nilai angka koefisien determinasi ( $R$ Square) sebesar 0,658 Hal ini berarti bahwa variabel Kesadaran merek, Persepsi Kualitas Loyalitas merek terhadap Keputusan Pembelian, mempunyai peranan 65,8\% secara bersama-sama untuk dapat menjelaskan atau menerangkan variabel Keputusan Pembelian. Sedangkan sisanya sebesar 44,2\% $(100 \%-48,2 \%)$ dijelaskan oleh variabel lain yang mempengaruhi Keputusan Pembelian 


\section{Hipotesis}

a. Uji Kelayakan Model

Uji kelayakan model dimaksudkan untuk mengetahui pengaruh Variabel Independent Kesadaran merek $\left(\mathrm{X}_{1}\right)$, Persepsi Kualitas $\left(\mathrm{X}_{2}\right)$ Loyalitas merek $\left(\mathrm{X}_{3}\right)$ terhadap Variabel Dependent Keputusan Pembelian (Y). Uji Kelayakan Model.

Berdasarkan tabel hasil pengujian statistik dengan menggunakan SPSS 16 didapatkan nilai $F_{\text {hitung }}=37,905$ sedangkan nilai $F_{\text {tabel }}(\mathrm{a}=0,05$, df pembilang $=\mathrm{k}=5 \mathrm{df}=(\mathrm{n}-\mathrm{k}),(\mathrm{k}-1)=($ $63-5),(5-1)=(58),(4) F_{\text {tabel }}=2.49$. $F_{\text {hitung }}(37,905)>F_{\text {tabel }}(2.49)$ Angka signifikansi $=$ $0,000<\mathrm{a}=0,05$ Dengan kriteria diatas maka Ho ditolak dan Ha diterima

Tabel 6

Uji Kelayakan Model

ANOVA $^{\mathrm{a}}$

\begin{tabular}{|l|r|r|r|r|r|}
\hline Model & Sum of Squares & df & Mean Square & F & Sig. \\
\hline \multirow{2}{*}{1} & 255.082 & 3 & 85.027 & 37.905 & $.000^{\mathrm{b}}$ \\
Regression & 132.346 & 59 & 2.243 & & \\
Residual & 387.429 & 62 & & & \\
\hline
\end{tabular}

a. Dependent Variable: Keputusan Pembelian

b. Predictors: (Constant), Loyalitas Merk, Kesadaran Merk, Persepsi Kualitas

Dari kriteria diatas dapat dinyatakan bahwa Ho ditolak dan Ha diterima atau dengan kata lain ada pengaruh yang signifikan antara, Kesadaran merek, Persepsi Kualitas, Loyalitas merek terhadap Keputusan pembelian handphone Vivo pada angkasa cell di Kota Semarang. Angka signifikansi ditunjukan pada tabel 6 sebesar 0,000 dan nilai $F$ hitung sebesar 37,905 yang berati layak atau fit.

b. Uji Hipotesis Parsial Dengan T-test

Uji t digunakan untuk mengetahui sejauh mana variabel bebas berpengaruh secara parsial terhadap variabel terikat, dengan tingkat kesalahan $5 \%$.

Hasil Uji Hipotesis Parsial Dengan t-test

Coefficientsa

\begin{tabular}{|rl|r|r|}
\hline Model & \multicolumn{1}{c|}{$\mathrm{t}$} & \multicolumn{1}{c|}{ Sig. } \\
\hline \multirow{3}{*}{1} & (Constant) & .585 & .560 \\
& Kesadaran Merk & 3.958 & .000 \\
& Persepsi Kualitas & 3.694 & .000 \\
& Loyalitas Merk & 3.438 & .001 \\
\hline
\end{tabular}

a. Dependent Variable: Keputusan Pembelian

a. Pengujian hipotesis 1

Variabel Kesadaran merek terhadap Keputusan pembelian handphone Vivo. Berdasarkan tabel Hasil Uji t untuk Variabel Kesadaran merek, diperoleh nilai thitung $=3,958$ Sedangkan $\mathrm{t}$ tabel $(\mathrm{a}=0,05, \mathrm{dk}=\mathrm{n}-4, \mathrm{dk}=63-3=60)$ adalah $1,66 \mathrm{t}_{\text {hitung }}(3,958)>\mathrm{t}_{\text {tabel }}(1,66)$ Angka 
signifikansi $=0,000<\mathrm{a}=0,05$ ( Ho ditolak dan Ha diterima ). Berdasarkan kriteria diatas dapat diketahui bahwa pada taraf signifikansi 0,05 variabel Kesadaran merek mempunyai pengaruh yang signifikan terhadap variabel Keputusan Pembelian.

b. Pengujian hipotesis 2

Variabel Persepsi Kualitas terhadap Keputusan Pembelian handphone Vivo. Berdasarkan tabel hasil Uji t untuk variabel, Persepsi Kualitas diperoleh nilai thitung $=3,694$ sedangkan $\mathrm{t}$ tabel $(\mathrm{a}=0,05, \mathrm{dk}=\mathrm{n}-3, \mathrm{dk}=63-3=60)$ adalah 1,66 thitung $(3,694)>$ ttabel $(1,66)$ Angka signifikansi $=0,000<\mathrm{a}=0,05$ (Ho ditolak dan Ha diterima). Berdasarkan kriteria diatas dapat diketahui bahwa pada taraf signifikansi 0,05 Variabel Persepsi Kualitas mempunyai pengaruh yang signifikan terhadap variabel Keputusan Pembelian.

c. Pengujian hipotesis 3

Variabel Loyalitas merek terhadap Keputusan Pembelian handphone Vivo. Berdasarkan tabel hasil Uji t untuk variabel Loyalitas merek, diperoleh nilai thitung $=3,348$ sedangkan ttabel $(\mathrm{a}=0,05, \mathrm{dk}=\mathrm{n}-3, \mathrm{dk}=63-3=60)$ adalah 1,66 thitung $(3,348)>$ ttabel $(1,66)$ Angka signifikansi $=0,001<\mathrm{a}=0,05$ (Ho ditolak dan Ha diterima). Berdasarkan kriteria diatas dapat diketahui bahwa pada taraf signifikansi 0,05 Variabel Loyalitas merek mempunyai pengaruh yang signifikan terhadap variabel Keputusan Pembelian.

\section{PEMBAHASAN}

1. Pengaruh Kesadaran merek tehadap Keputusan pembelian handphone Vivo pada angkasa cell di Kota Semarang.

Hasil penelitian menunjukan bahwa variabel Kesadaran merek mempunyai pengaruh Positif dan signifikan terhadap Keputusan pembelian handphone Vivo pada angkasa cell di Kota Semarang. Hal ini ditunjukan dengan nilai koefesien regresi terbesar 0,301. Sedangkan untuk nilai $\mathrm{t}_{\text {hitung }}(3,958)>\mathrm{t}_{\text {tabel }}(1,66)$ dan sign $(0,000)<\operatorname{sign} a(0,05)$, sehingga hipotesis pertama yang diajukan ada pengaruh Positif dan signifikan variabel Kesadaran merek terhadap Keputusan pembelian handphone Vivo pada angkasa cell di Kota Semarang.

Hasil penelitian ini sejalan dengan penelitian yang dilakukan oleh Sumiati (2008). menunjukkan bahwa hasil penelitian ini, adanya pengaruh kesadaran merek konsumen, persepsi kualitas, sikap konsumen, dan brand image secara bersama terhadap keputusan Pembelian Tablet Apple Ipad.

2. Pengaruh Persepsi Kualitas terhadap Keputusan pembelian handphone Vivo pada angkasa cell di Kota Semarang. 
Hasil penelitian ini menunjukan bahwa variabel Persepsi Kualitas mempunyai pengaruh yang signifikan terhadap Keputusan pembelian handphone Vivo pada angkasa cell di Kota Semarang. Hal ini menunjukan dengan nilai koefesien regresi sebesar 0,303. Sedangkan untuk nilai thitung $(3.694)>\mathrm{t}_{\text {tabel }}(1,66)$ dan $\operatorname{sign}(0,000)<\operatorname{sign} a(0,05)$, sehingga hipotesis kedua yang diajukan ada pengaruh positif dan signifikan Persepsi Kualitas terhadap Keputusan pembelian handphone Vivo pada angkasa cell di Kota Semarang, terbukti dapat diterima.

Hasil penelitian ini tidak sejalan dengan penelitian yang dilakukan oleh Raja Bongsu Hutagalung dan Novi Aisha (2012), yang menunjukkan bahwa Faktor kebudayaan, faktor sosial berpengaruh secara positif dan signifikan terhadap keputusan konsumen. Faktor pribadi, faktor psikologi berpengaruh secara positif dan tidak signifikan terhadap keputusan konsumen.

3. Pengaruh Loyalitas merek terhadap Keputusan pembelian handphone Vivo pada angkasa cell di Kota Semarang.

Hasil penelitian ini menunjukan bahwa variabel Loyalitas merek mempunyai pengaruh yang signifikan terhadap Keputusan handphone Vivo pada angkasa cell di Kota Semarang. Hal ini menunjukan dengan nilai koefesien regresi sebesar 0,242. Sedangkan untuk nilai thitung $(3.438)>\mathrm{t}_{\text {tabel }}(1,66)$ dan sign $(0,001)<\operatorname{sign} a(0,05)$, sehingga hipotesis ketiga yang diajukan ada pengaruh positif dan signifikan Loyalitas merek terhadap Keputusan pembelian handphone Vivo pada angkasa cell di Kota Semarang, terbukti dapat diterima.

Hasil penelitian ini juga sejalan dengan penelitian yang dilakukan oleh Jesica Monica Reppi, Altje Tumbel, Rotinsulu Jopie Jorie (2015), yang menunjukkan bahwa, Persepsi kualitas, kesadaran merek dan sikap konsumen berpengaruh positif signifikan terhadap keputusan pembelian ponsel iphone pada pusat perbelanjaan ITC Manado.

\section{KESIMPULAN}

1. Kesadaran merek mempunyai pengaruh Positif dan signifikan terhadap Keputusan pembelian handphone Vivo pada angkasa cell di Kota Semarang. Hal ini ditunjukan dengan nilai koefesien regresi terbesar 0,301. Sedangkan untuk nilai t hitung 3,958 > ttabel 1,66 dan sign 0,000 .

2. Persepsi Kualitas mempunyai pengaruh yang signifikan terhadap Keputusan pembelian handphone Vivo pada angkasa cell di Kota Semarang. Hal ini menunjukan dengan nilai koefesien regresi sebesar 0,303. Sedangkan untuk nilai thitung $3.694>$ ttabel 1,66 dan sign 0,000 
3. Loyalitas merek mempunyai pengaruh yang signifikan terhadap Keputusan handphone Vivo pada angkasa cell di Kota Semarang. Hal ini menunjukan dengan nilai koefesien regresi sebesar 0,242. Sedangkan untuk nilai thitung 3.438 > ttabel 1,66 dan sign 0,001

\section{DAFTAR PUSTAKA}

Aaker, David A. (1996). Manajemen Ekuitas Merek. (Alih bahasa: Aris Ananda). Jakarta: Spektrum Mitra Utama

David.A., 1991, Manajemen Equitas Merek, mamanfaatkan nilai dari suatu merek. Jakarta: Mitra Utama

and Nagar. 2009. "Managing Assets and Skills : A Key to a Sustainable Competitive Advantage". California Management Review Vol. 31 (Winter). pp. 91-106.

Assael, Henry. (1998) Cunsumer Behavior and Marketing Action, 6th Edition, Southwestern College Publishing: Cincinnati, Ohio

Arikunto, Suharsimi (ed). 1992. Prosedur Penelitian Suatu Pendekatan Praktek. Edisi Revisi. Jakarta: Rineka Cipta

Arikunto, Suharsimi. (2010). Prosedur Penelitian: Suatu Pendekatan Praktek. Jakarta: PT Rineka Cipta.

Bruhn, M., Schoenmueller, V., \& Schafer, D.B. (2012). Are Social Media Replacing Traditional Media in Terms of Brand Equity Creation? Management Research Review, Vol.35 No.9, pp.770-790.

Cronin, J Joseph dan Morris A Taylor. 1989. “Measuring Service Quality : A Reexamination and Extension". Journal of Marketing Vol. 56 (July). pp. 55-68.

Chang, Hsin Hsin, Hsu Che-Hao dan Chung, Shu Hsia. (2008). The Antecedents and Consequences of Brand Equity in Service Markets. Asia Pasific Management Review, 13(3), 2008.

C. Mowen, John. Michael Minor. 2002. Perilaku Konsumen. Jakarta. Erlangga

Durianto, D, Sugiarto, \& Sitinjak, T. (2004). Strategi Menaklukkan Pasar Melalui Riset Ekuitas dan Perilaku Merek. Jakarta: PT. Gramedia Pustaka Utama.

Durianto, Darmadi, Sugiarto dan Tony, Simanjuntak, "Strategi Menaklukan Pasar Melalui Riset Ekuitas dan Perilaku Merek", PT. Gramedia Pustaka Utama, Jakarta, 2004.

Gujarati. 2003. Ekonometrika Dasar terj. Sumarno Zein. Jakarta: Erlangga.

Ghozali, Imam (20011). Aplikasi Analisis Multivariate dengan Program IBM SPSS 19. Semarang: Badan Penerbit Universitas Diponegoro 
Ghozali, Imam. 2005. Aplikasi Analisis Multivariate Dengan Program SPSS. Semarang: Badan Penerbit Universitas Diponegoro.

Giddens. 2002. Customer Loyalty : Menumbuhkan dan Mempertahankan Kesetiaan Pelanggan. Ahli Bahasa : Dwi Kartini Jaya. Edisi Revisi dan Terbaru. Jakarta : Erlangga.

Gujarati, Damodar (1999) Essentials of Econometrics. Boston: Mc Graw-Hill Huang, C. C, et. al. (2014). The Relationship Among Brand Equity, Custom

Hawkins, Del I (2007). Consumer Behavior: Building Marketing Strategy. New York: Irwin McGraw-Hill

Jogiyanto (2008). Pedoman Survey Kuesioner. Yogyakarta: BPFE

Kartajaya, Hermawan. (2004). Hermawan Kartajaya On Branding. Bandung: Mizan Media Utama

Kim, H.B. ve Kim, W.G. (2005) The Relationship Between Brand Equity and Firms' Performance in Luxury Hotels and Chain Restaurants, Tourism Management, 26:549-560

Kriyantono, Rachmat.2006. Teknik Praktis Riset Komunikasi. Jakarta: Kencana

Kotler Philip dan Amstrong, (2001). Prinsip-Prinsip Manajemen, Jilid 1 Edisi Kedelapan, Alih Bahasa Oleh Damos Sihombing, MBA., Jakarta: Penerbit Erlangga

Kotler, Philip dan Kevin Lane Keller (2009). Manajemen Pemasaran (Edisi Kedua Belas) Jakarta: Cetakan Ketiga, PT. Indeks

Malhotra. 2005. Riset Pemasaran. Jilid I. Edisi 4. Jakarta: Indeks Kelompok Gramedia

Paul, Peter. J dan Jerry C. Olson, 2000, Consumer Behaviour : Perilaku Konsumen dan Strategi Pemasaran, jilid 1 dan jilid 2, Jakarta : Erlangga.

Redaksi Majalah SWA (2007). Market share 2007. SWA No. 16/XXII/Juli Agustus 2007

Redaksi Majalah SWA (2008). Market share 2008. SWA NO. 18/XXIV/Agustus-September 2008 Redaksi Majalah SWA (2009). Market share 2009. SWA NO.16/XXV/Juli Agustus 2009

Redaksi Majalah SWA (2010). Market share 2010. SWA NO.15/XXVI/15-18 Juli 2009

Redaksi Majalah SWA (2011). Market share 2011. SWA NO.15/XXVII/15-27 Juli 2011

Rangkuti, Freddy. ((2009). Strategi Promosi yang Kreatif dan Analisis Kasus Integrated Marketing Communication. Jakarta : PT. GramediaPustakaUtama

Simamora, Bilson. (2001). "Remarketing for Business Recovery, Sebuah Pendekatan Riset". Jakarta: Gramedia PU

Simamora, Bilson.(2004) Panduan Riset Perilaku Konsumen. Jakarta: Gramedia PU 
Sudarmadi (2014). Top 250 Indonesia Brand 2014. SWA edisi 16 (21 Juli-13 Agustus 2014). Hlm. 33-38

Sutrisno, 2001, Manajemen Keuangan, Edisi Pertama, Cetakan Kedua, EKONISIA, Yogyakarta.

Sugiyono. (2007). Metode Penelitian Bisnis. Bandung : CV Alfabeta. 2008. Metode Penelitian Administrasi. Bandung: Alfabeta. . 2009. Metode Penelitian Kuantitatif. Bandung: Alfabeta.

Schiffman, L. \& Kanuk, L, L. (2009). Perilaku Konsumen (edisi 7). Indeks. Jakarta.

Zeithaml, Valarie A., Mary Jo Bitner, dan Dwayne D. Gremler. (2006). Service Marketing Integrating Customer Focus Accross The Firm 4th Edition. New York:McGraw Hill. 